\title{
CHAPTER 4.5 PROTEOLYTIC EXTRACTS OF THREE BROMELIACEAE SPECIES AS ECO-COMPATIBLE TOOLS FOR LEATHER INDUSTRY
}

\author{
M. E. Errasti *(1); N. O. Caffini (1) and L. M. I. Lopez (2)
}

(1) CIProVe, FCE, UNLP, Calle 47 \& 115, La Plata, Argentina

(2) Centro de Investigación y Tecnología del Cuero (CITEC), CIC-INTI. Camino Parque Centenario e/ 505 \& 508. Manuel B. Gonnet, Argentina

\section{ABSTRACT}

In addition to the large quantities of solid waste rich in protein, most tanneries use high proportions of $\mathrm{Na}_{2} \mathrm{~S}$ and $\mathrm{CaO}$ during the dehairing step, resulting in effluents of high alkalinity and large amounts of suspended solid, besides the risk of liberating the toxic hydrogen sulphide. The current worldwide legislation on environmental requires tanneries to reduce pollution and to replace conventional processes by greener technologies.

Enzymes are a technological tool of interest for industry because are able to achieve a high reaction rate under soft $\mathrm{pH}$, temperature, and pressure conditions, besides a high specificity of reaction, biodegradability, non-toxic nature and non-polluting effluent generation. In leather industry enzymes are principally used in pre-tanning operations (soaking, dehairing, bating, and degreasing) and waste treatment. Particularly, proteases have been chosen as a promising eco-friendly alternative to lime and sodium sulphide dehairing.

Extracts rich in cysteine proteases with high proteolytic activity $(\mathrm{CU})$ have been obtained from fruits of Bromeliaceae species: Bromelia balansae (Bb), B. hieronymi (Bh), and Pseudananas macrodontes (Pm). In this work, $\mathrm{Bb}, \mathrm{Bh}$, and $\mathrm{Pm}$ have been studied for application in leather industry compared with commercial enzyme, focusing in their dehairing properties. Enzymatic activities against representative substrates of skin proteins were spectrophotometrically measured at 25,35 , and $55^{\circ} \mathrm{C}($ Tris- $\mathrm{HCl}, 0.1 \mathrm{M}, \mathrm{pH}$ 8, Cys $20 \mathrm{mM}$ ). Keratin Azure (KA), Elastin-Congo Red (E), epidermis substrate (EP), and Hide Powder Azure (HPA) were used as representative substrates of keratin, elastin, epidermis, and collagen, respectively. Ability to dehairing was evaluated by incubating soaked cow skins with different concentrations of extracts at $25^{\circ} \mathrm{C}$ and $\mathrm{pH} 8$ during $24 \mathrm{~h}$. Grain surface and cross section of skins were observed by scanning electron microscopy.

Extracts were able to degrade representative substrates of skin proteins and when compared to the same CU showed similar activity on collagen and epidermis; however, $\mathrm{Bh}$ and $\mathrm{Pm}$ were the most actives against keratin, while Bh was the only active against elastin. Extracts showing different proteolytic activity $(\mathrm{Bb}$ required $1 \mathrm{CU} / \mathrm{ml}, \mathrm{Bh} 1.5$ $\mathrm{CU} / \mathrm{ml}$, and $\mathrm{Pm} 0.5 \mathrm{CU} / \mathrm{ml}$ ) were able to depilate cow skin after a gentle scraping. Although depilated skins with $\mathrm{Bb}, \mathrm{Bh}$, and Pm showed different surface aspects, desirable characteristics of dehairing were observed for all extracts since hair pores did

*Author for correspondence: eerrasti@gmail.com 


\section{ISEBE Advances 2016}

not show residual hair, grain surface were clean and intact, and collagen fiber bundles of dermis were not damaged.

In conclusion, results here presented show that proteolytic extracts of Bromeliaceae species are promising eco-compatible tools for leather industry, principally in treatment of their waste and dehairing process.

Keywords: Bromeliaceae; dehairing; leather; plant proteases

\section{INTRODUCTION}

Leather has played a key role in the development of human civilization and leather industry has had an important contribution in economy of many countries, with a rising worldwide market for the coming years ${ }^{1,2}$. Despite those benefits, it has a negative image in society due to the use of toxic chemicals for human health and their wastes (solid, liquid and gaseous) which it means a source of environmental pollution. Accordingly, the current worldwide legislation on environmental requires tanneries to reduce pollution and to replace conventional processes by greener technologies ${ }^{3}$.

The goal of leather manufacture is transform unstable skins or hides in leather, but only $15-25 \%$ of hide weight is converted into leather and the rest are solid wastes, mainly constituted by proteins ${ }^{4,5}$. Leather processing involves a series of unit operations that can be classified into three groups: (i) pre-tanning or beamhouse operations, which clean the hides or skins; (ii) tanning, which permanently stabilizes the skin or hide matrix; and (iii) post-tanning and finishing operations, where aesthetic value is added 6 . Among the pre-tanning operations, dehairing is an important step in which hair along with epidermis, non collagenous proteins and other cementing substances are removed from the skin?

The conventional dehairing process employs lime (calcium oxide) and sodium sulphide, contributing to most of pollution generated in pre-tanning operations ${ }^{2,3,5,6}$. Due to the low solubility of the commercial grade of used lime, its use has the disadvantage of generating large quantities of solid waste which requires being disposed safely ${ }^{8}$, besides of subsequent acid treatment of the resulting alkaline effluent ${ }^{9}$. Use of sodium sulphide has the risk of liberating hydrogen sulphide, a toxic gas which is a health hazard to the tannery workers and sewer men ${ }^{10}$. On the other hand, during this process the hair is largely disintegrated by hydrolysis of keratin, contributing to the biochemical oxygen demand (BOD) and chemical oxygen demand (COD) of the wastewater $6,8,11$. Consequently, conventional dehairing processes generates $83 \%$ of BOD, $73 \%$ of COD, $60 \%$ of suspended solids, and $76 \%$ of the total polluting charge produced during the manufacturing process of hides ${ }^{5}$.

Thereby, finding a cleaner alternative to lime-sulphide dehairing constitutes an efficient strategy for reducing the negative impact of tanneries on environment. Enzymes are a technological tool of interest for industry because are able to achieve a high reaction rate under soft $\mathrm{pH}$, temperature, and pressure conditions, besides a high specificity of reaction, biodegradability, non toxic nature and non polluting effluent generation ${ }^{12}$. In leather industry enzymes are principally used in pre-tanning operations (soaking, dehairing, bating, and degreasing $)^{3,6,12,13}$ and waste treatment ${ }^{12,14}$. Among those enzymes, proteases are highlighted because skin is mostly constituted by different 


\section{ISEBE Advances 2016}

proteins which are the targets in the various steps of leather processing. Moreover, proteases have been chosen as a promising alternative to lime and sodium sulphide dehairing. Several works have shown the efficacy and environmental benefits of enzyme-based dehairing, such as reduction in effluent pollution, reduction of solid waste and lime sludge, reduction of total solids and neutral $\mathrm{pH}$ of effluents. In addition, due to poor keratinolytic activity of used enzymes, the hair is removed intact, leading to low $B O D$ and $C O D$ in the effluent and allowing its use as raw material for other industries.

However, there is yet some reticence in industry to apply this technology, among other reasons, because of the risk of collagen degradation, protein that form the basic skin structure. As leather quality is closely related to state and quantity of skin proteins ${ }^{11,13,15}$ is essential to know the enzyme specificity on representative substrates of skin to improve efficiency $8,13,16$.

Several cysteine proteases have been isolated and characterized in our research group from plant species belonging to the family Bromeliaceae. Particularly, proteolytic extracts with suitable properties for industrial applications, such as high thermal stability and neutral or slightly alkaline (6-10) optimum $\mathrm{pH}$ range, have been obtained from fruits of Bromelia balansae $(\mathrm{Bb})^{17}, \mathrm{~B}$. hieronymi $(\mathrm{Bh})^{18,19,20}$, and Pseudananas macrodontes $(\mathrm{Pm})^{21,22,23}$. In this work, proteolytic extracts rich in cysteine proteases $(\mathrm{Bb}, \mathrm{Bh}$, and $\mathrm{Pm})$ have been studied for application in leather industry, focusing in their dehairing properties. To understand enzyme action on skin, proteolytic activity on representative substrates of skin protein was measured at 25,35 , and $55^{\circ} \mathrm{C}$ and $\mathrm{pH} 8$. Additionally, to evaluate dehairing action, assays were carried out by employing pieces of cow skin.

\section{MATERIAL AND METHODS}

Chemicals. Casein (from bovine milk), Coomassie brilliant blue G-250, cysteine, bovine serum albumin, Elastin-Congo Red, Hide Powder Azure, Keratin Azure, and Tris were purchased from Sigma-Aldrich (St. Louis, Missouri, USA). Ethylenediaminetetraacetic acid was purchased from Invitrogen (Carlsbad, California, USA), sodium phosphate (98\%) from Carlo Erba (Rodano, MI, Italy), detergent Azymol 6SE from Pellital (Victoria, BA, Argentina). All other chemicals were of analytical grade.

\section{Plant material.}

Bromelia hieronymi. Mez fruits were collected by Prof. Lucas Roic in Santiago del Estero, Argentina. A voucher specimen (Leg. Venturi, LP7050) was deposited at the herbarium of the Vascular Plant Division, Faculty of Natural Sciences and Museum, National University of La Plata, Argentina. Infructescences of B. balansae Mez and Pseudananas macrodontes (Morr.) Harms fruits were collected by Dr. Aníbal Amat (National University of Misiones) in Santa Ana, Province of Misiones, Argentina. Voucher specimens (Leg. Amat, No. 1596-7) were deposited at the herbarium of the Faculty of Exacts, Chemical and Natural Sciences of the National University of Misiones, Posadas, Argentina. Fruits were washed with distilled water, dried, and stored at $-20^{\circ} \mathrm{C}$ until extraction. 


\section{ISEBE Advances 2016}

Enzymatic preparations. Each plant extract was obtained by chopping and homogenizing frozen unripe fruits with $0.1 \mathrm{M}$ sodium phosphate buffer containing ethylenediaminetetraacetic acid and cysteine as protective agents ${ }^{17,18,21}$. The homogenate was filtered and centrifuged. Then, supernatant was collected, lyophilized, and stored at $-20^{\circ} \mathrm{C}$. For all assays, samples of proteolytic extracts were prepared by dissolving the lyophilized powder in reaction buffer $($ Tris- $\mathrm{HCl} 0.1 \mathrm{M}, \mathrm{pH} 8.0$, containing cysteine $20 \mathrm{mM}$ ).

In order to comparing dehairing action with a commercial dehairing enzyme, New1875 from CERGEN LLC was used.

Determination of proteolytic activity and protein content. Caseinolytic activity assays were carried out to determine the proteolytic activity by using casein as substrate $(1 \%$ $\mathrm{w} / \mathrm{v}$ in reaction buffer) at $37^{\circ} \mathrm{C}$. An arbitrary enzyme unit (caseinolytic unit, $\mathrm{CU}$ ) was used to express proteolytic activity ${ }^{21}$.

Protein content was determined by the Bradford ${ }^{24}$ method, using bovine serum albumin as standard.

\section{Proteolytic assays on representative substrates of skin proteins}

Hide Powder Azure (HPA) substrate ${ }^{25}$. Sample (100 $\mu$ ) was incubated with HPA (5 mg in $1.9 \mathrm{ml}$ of reaction buffer) under magnetic stirring during 5 , 10, and $15 \mathrm{~min}$. Subsequently, dispersion was centrifuged and absorbance of the supernatant was measured at $595 \mathrm{~nm}$ (Abs595). Blank determination was made replacing sample by reaction buffer. The unit of activity on HPA (U UPA) was defined as the enzyme amount per ml that increases 0.001 units of Abs595 per min.

Elastin-Congo Red $(E)$ substrate ${ }^{25}$. Sample $(250 \mu \mathrm{l})$ was incubated with $\mathrm{E}(5 \mathrm{mg}$ in 1.75 $\mathrm{ml}$ of reaction buffer) under magnetic stirring during 15, 30, 60, 90, and $120 \mathrm{~min}$. Subsequently, dispersion was centrifuged and absorbance of the supernatant was measured at $495 \mathrm{~nm}$ (Abs495). Blank determination was performed. Elastinolytic activity unit $\left(U_{E}\right)$ was defined as the enzyme amount per $\mathrm{ml}$ that increases 0.001 units of Abs495 per min.

Keratin Azure (KA) substrate ${ }^{25}$. Sample $(100 \mu \mathrm{l})$ was incubated with KA (3 mg in $1 \mathrm{ml}$ of reaction buffer) during $24 \mathrm{~h}$. Abs595 of reaction liquid was measured at $0.5,1,2,4$, and $24 \mathrm{~h}$. Blank determination was performed. Keratinolytic activity unit (UKA) was defined as the amount of enzyme per $\mathrm{ml}$ that increases 0.001 units of Abs595 per min.

Epidermis (EP) substrate. Sample $(100 \mu \mathrm{l})$ was incubated with epidermis substrate ${ }^{25}(20$ $\mathrm{mg}$ in $1.9 \mathrm{ml}$ of reaction buffer) under magnetic stirring during 20, 40, and $60 \mathrm{~min}$. Reaction was stopped by addition of $1.5 \mathrm{ml}$ of TCA (5\%). Then, dispersion was centrifuged and absorbance of supernatant measured at $280 \mathrm{~nm}$ (Abs280). Blank determination was performed. The unit of activity on epidermis ( $\left.U_{E P}\right)$ was defined as the amount of enzyme per $\mathrm{ml}$ that increases 0.001 unit of Abs280 per min. 


\section{ISEBE Advances 2016}

Dehairing experiments. Pieces of $4 \mathrm{~g}$ were cut from wet-salted cow hide. Prior to dehairing, soaking was carried out by incubating pieces in $20 \mathrm{ml}$ of soaking bath $(0.2 \%$ of bactericide, $0.3 \%$ of detergent, and $0.13 \%$ of $\left.\mathrm{Na}_{2} \mathrm{CO}_{3}\right)$ at $25{ }^{\circ} \mathrm{C}$ during $24 \mathrm{~h}$. Dehairing assay was performed by immersing each piece into $20 \mathrm{ml}$ of reaction buffer containing different concentrations $(\mathrm{CU} / \mathrm{ml})$ of proteolytic extract. After $24 \mathrm{~h}$ at $25^{\circ} \mathrm{C}$ with orbital stirring $(\omega=75 \mathrm{rpm})$, pieces were withdrawn from baths and hair was removed by a standardized gentle scraping. Samples were cut from depilated pelts, washed and fixed in formal saline.

Microscopy analyses. Samples of fixed pelts were cut with uniform thickness, washed, dehydrated with a graded ethanol series, and then coated with gold. The micrographs of the grain surface and cross section were obtained by operating the Scanning Electron Microscopy (FEI, Quanta 200) from the Service Electronics Microscopy and Microanalysis (SEM-LIMF) of Faculty of Engineering of UNLP (Argentina), with an accelerating voltage of $20 \mathrm{KV}$ in different lower and higher magnification levels.

Data analyses. Results of activity assays were obtained from three independent experiments done in duplicate and data expressed as mean \pm SD. Previously the linear range of enzymatic reaction for each assay was determined. The data were analyzed with One Way ANOVA followed by Tukey Multiple Comparison test.

\section{RESULTS AND DISCUSSION}

Extracts obtained from fruits of Bromelia balansae (Bb), B. hieronymi (Bh), and Pseudananas macrodontes showed proteolytic activity per expected ${ }^{17,18,21}$ (Table 1). Bh was the extract with the highest activity per mg of preparation, but if the protein content is considered, $\mathrm{Bb}$ had the highest specific activity (CU/pg protein) with a value of 0.012 , like that of the commercial product New 1875, which was 0.015 .

TABLE 1. Caseinolytic activity (CU) and protein content ( $\mu$ gpro) per $\mathrm{mg}$ of preparation. $\mathrm{CU}$, caseinolytic units (pH 8). Mean \pm SD

\begin{tabular}{ccc}
\hline Sample & $\begin{array}{c}\text { Caseinolytic activity } \\
\text { (CU/mg) }\end{array}$ & $\begin{array}{c}\text { Protein } \\
\text { ( } \boldsymbol{\mu g p r o / m g )}\end{array}$ \\
\hline $\mathrm{Bb}$ & $0.04 \pm 0.01$ & $3.38 \pm 0.06$ \\
$\mathrm{Bh}$ & $0.17 \pm 0.02$ & $22 \pm 3$ \\
$\mathrm{Pm}$ & $0.09 \pm 0.02$ & $15 \pm 4$ \\
New1875 & $0.09 \pm 0.01$ & $6 \pm 1$ \\
\hline
\end{tabular}

Casein is an adequate substrate to measure total proteolytic activity due to that mimics closely the natural substrates of proteolytic enzymes ${ }^{26}$, but it is a non specific substrate. The goal of this work is to study the extracts as a possible technology for the skin treatments used during leather manufacture, for which it is suitable to know their activities on skin proteins. Keratin Azure (KA), elastin-Congo Red (E), and HPA were used as representative substrates of keratin, elastin and collagen, respectively. Epidermis substrate (EP) is epidermis layer, hair follicle, and hair removed from skin ${ }^{25}$. 
Because keratin is the main protein of epidermis layer and hair, epidermis substrate is also representative of keratin.

In Figure 1 are shown activities on KA, HPA, E and EP at 25, 35, and $55^{\circ} \mathrm{C}$. Except elastinolytic activities of $\mathrm{Bb}$ and $\mathrm{Pm}$, activities increased with temperature. Therefore, temperature is a variable that could be operated to regulate the activities according to the desired effect. It has reported that the three proteolytic preparations keep the activity between $50-90 \%$ after $2 \mathrm{~h}$ at $55^{\circ} \mathrm{C}^{17,18,23}$, thus this temperature could be chosen if they are wanted to use for high protein waste treatment.
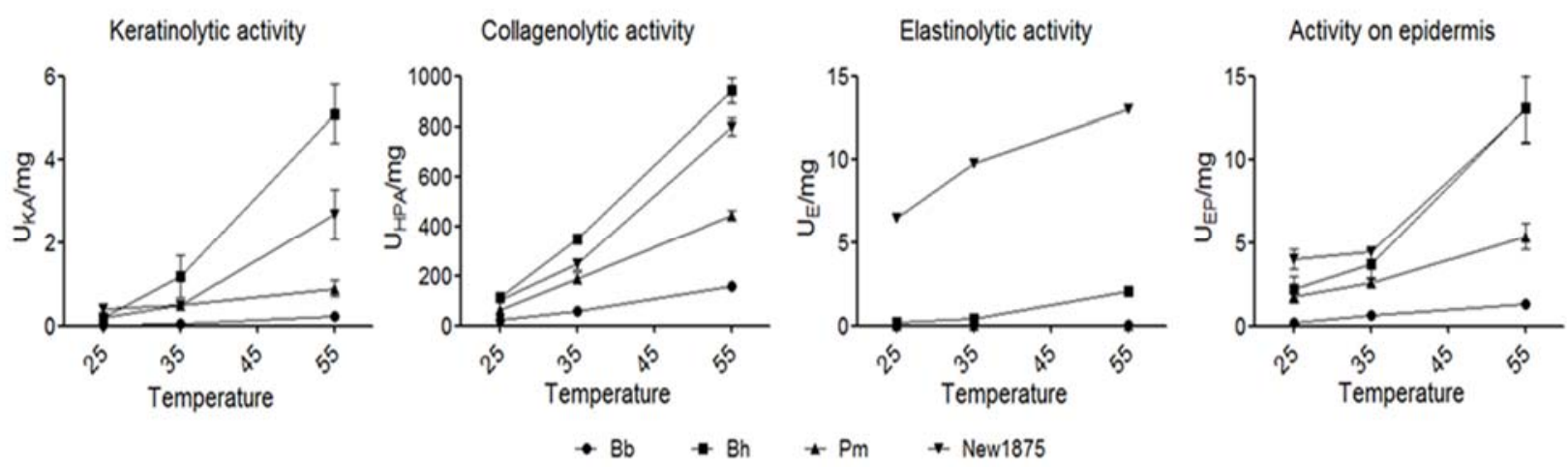

FIGURE 1. Activity on representative substrates of skin proteins as a function of temperature. Mean \pm SD

Bh was the plant extract most active on all substrates; however, it could be due to major proteolytic activity per $\mathrm{mg}(\mathrm{CU} / \mathrm{mg})$ of Bh, per Table 1 . To compare extracts regardless of their total proteolytic activity, activities on each substrate were normalized to the same caseinolytic unit (1 CU), which are shown for $35^{\circ} \mathrm{C}$ in Table 2.

TABLE 2. Normalized activity on representative substrates of skin proteins at $35^{\circ} \mathrm{C}$

\begin{tabular}{ccccc}
\hline Sample & $\mathbf{U}_{K A} / C U$ & $U_{H P A} / C U$ & $U_{E} / C U$ & $U_{E P} / C U$ \\
\hline$B b$ & $1^{\mathrm{a}} \pm 0.3$ & $1840^{\mathrm{a}} \pm 93$ & $1.1^{\mathrm{a}} \pm 0.2$ & $17^{\mathrm{a}} \pm 5$ \\
$\mathrm{Bh}$ & $7^{\mathrm{b}} \pm 3$ & $2052^{\mathrm{ab}} \pm 75$ & $2.5^{\mathrm{b}} \pm 0.3$ & $22^{\mathrm{ab}} \pm 5$ \\
$\mathrm{Pm}$ & $5^{\mathrm{b}} \pm 1$ & $2305^{\mathrm{b}} \pm 255$ & $0.46^{\mathrm{a}} \pm 0.04$ & $29^{\mathrm{b}} \pm 3$ \\
New1875 & $5^{\mathrm{b}} \pm 2$ & $2468^{\mathrm{b}} \pm 235$ & $98^{\mathrm{c}} \pm 2$ & $45^{\mathrm{c}} \pm 2$ \\
\hline
\end{tabular}

Keratinolytic activity, activity on HPA, elastinolytic activity, and activity on epidermis were expressed as activity units per caseinolytic unit $\left(\mathrm{U}_{K A} / \mathrm{CU}, \mathrm{U}_{\mathrm{HPA} / \mathrm{CU}} \mathrm{U}_{E} / \mathrm{CU}\right.$, and $\mathrm{U}_{\mathrm{EP}} / \mathrm{CU}$, respectively). Tukey's test: the means with one common superscript letter are not significantly different at $p<0.05$. Mean $\pm S D$

Bh and Pm showed similar effect on collagen and keratin than those of the New1875 while $\mathrm{Bb}$ was slightly lower. Collagen is a protein arranged in fiber bundles which form the basic skin structure and, due to that is closely related with quality of leather, its degradation must be minimized during the leather manufacture ${ }^{11,13,15}$. However, high collagenolytic activity is desirable if enzyme is used to degrade waste solid from tannery. Among plant extracts, Bh was the most active against elastin.

The major differences between plant extracts and the commercial enzyme were found in elastinolytic activity and activity on epidermis substrate. High elastinolytic activity has been reported for enzymes used in soaking and bating ${ }^{13}$, two steps of pre-taining 


\section{ISEBE Advances 2016}

process in which undesirable proteins are removed. During soaking, previous to dehairing, fats and non collagenous proteins present between collagen fibers are removed, leading to opening up of theses fibres facilitating rehydration of the skin ${ }^{6}$ necessary to diffusion of chemical agents during making of leather ${ }^{26}$. Bating is the subsequent step to dehairing, which cause physicochemical changes in the skin 6 . During this process continues the opening up of collagen fibers and the hide structure is softened $^{13}$, making the leather soft and easier to dye ${ }^{1}$. Removal of elastin has been associated to softness and flexibility of the final leather ${ }^{25,28}$ and it has been suggested having some effect in loosening proteins around the base of the hair follicles ${ }^{13}$.

Even when some keratinases can act as an excellent eco-friendly dehairing system ${ }^{16,29}$, also it has been found that keratinase activity, measured from the KA assay, is not important for good removal of hair ${ }^{13}$. Because the dehairing process consists mainly in removal of epidermal layer and hair, activity on epidermis substrate could be a better measurement of dehairing action.
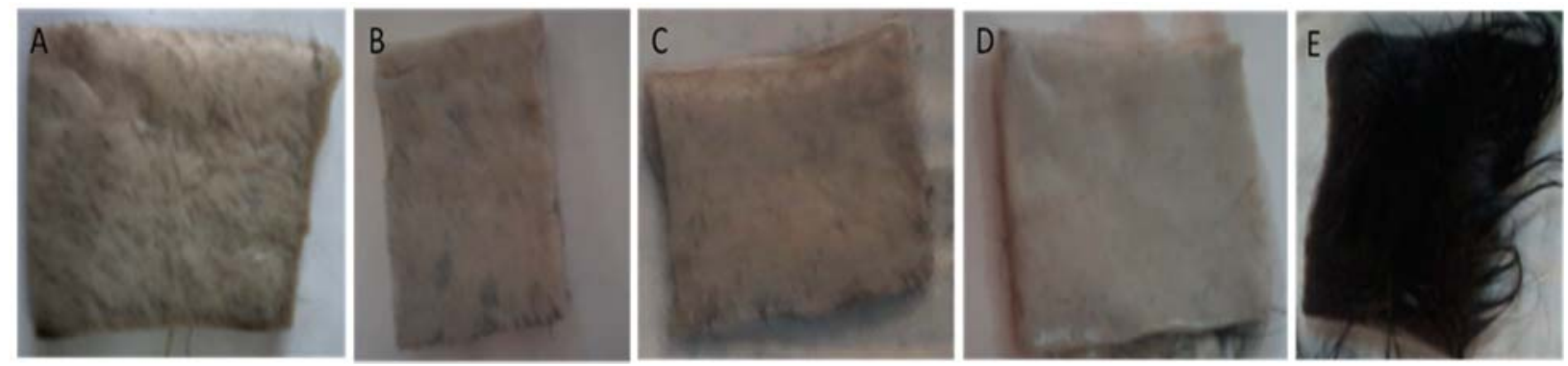

FIGURE 2. Images of cow skins after treatment with: (A) $1 \mathrm{CU} / \mathrm{ml}$ of $\mathrm{Bb}$; (B) $1.5 \mathrm{CU} / \mathrm{ml}$ of $\mathrm{Bh}$; (C) $0.5 \mathrm{CU} / \mathrm{ml}$ of Pm; (D) $0.2 \mathrm{CU} / \mathrm{ml}$ of New1875; (E) reaction buffer (Control).

Ability to dehairing was evaluated by incubating soaked cow skins with different proteolytic activities $(\mathrm{CU} / \mathrm{ml})$ of extracts. Due to the activity on collagen greatly increases with temperature (Figure 1), $25^{\circ} \mathrm{C}$ was chosen as incubation temeperature, to diminish collagen degradation. For each enzymatic sample, it was determined the minor concentration of CU capable of uniformly removing hair from entire skin area by a gentle scraping: $0.2 \mathrm{CU} / \mathrm{ml}$ of New1875, $0.5 \mathrm{CU} / \mathrm{ml}$ of $\mathrm{Pm}, 1 \mathrm{CU} / \mathrm{ml}$ of $\mathrm{Bb}$, and $1.5 \mathrm{CU} / \mathrm{ml}$ of $\mathrm{Bh}$ (Figure 2). In Figure 3 are shown the percentage relative activity on substrates (considering $100 \%$ to the highest activity) for concentration of each enzymatic preparation used to depilate during the dehairing assay.

Although the values of keratinolytic activity and activity on epidermis were the most similar between the samples used at different concentrations to depilate, no activity on substrate could be considered completely representative of the dehairing action. However, it could conclude that elastolytic activity is not essential to depilate, which is in accordance with Foroughi et al $(2006)^{13}$. In view of skin complexity, it is probably that other target skin proteins of the dehairing agent had been degraded.

On the other hand, it is remarkable that the dehairing action of $\mathrm{Bb}$ and $\mathrm{Pm}$ coexisted with lower collagenolytic activity than that of Bh, although higher than that of New1875, which also had the highest elastinolytic activity. 


\section{ISEBE Advances 2016}

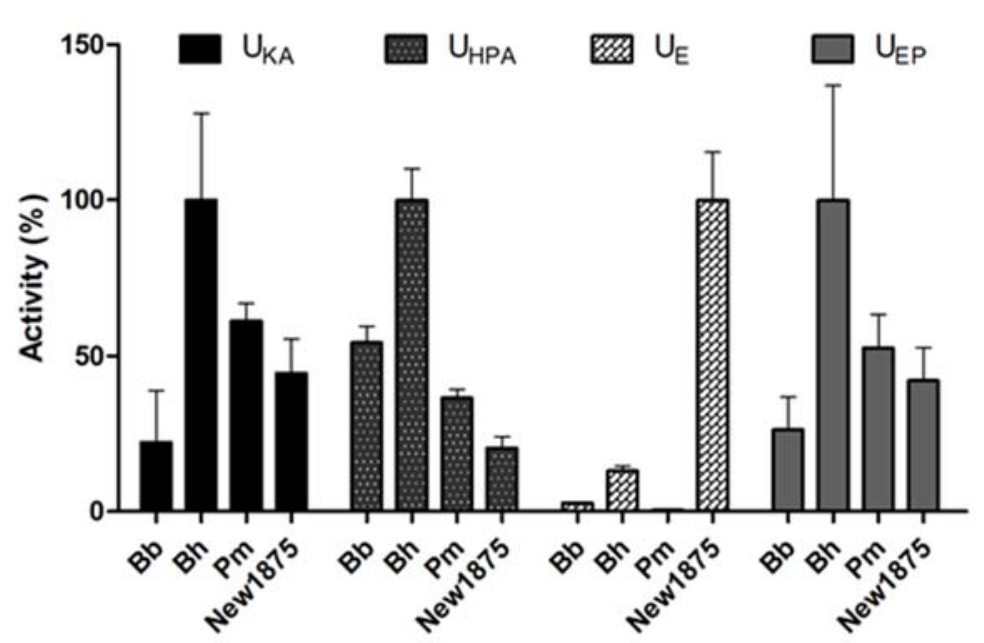

FIGURE 3. Percentage relative activity on substrates used in the dehairing experiment. $\mathrm{U}_{\mathrm{KA}}$, keratinolytic activity unit; $\mathrm{U}_{\mathrm{HPA}}$, activity unit on HPA; $\mathrm{U}_{\mathrm{E}}$, elastinolytic activity unit; $U_{E P}$, activity unit on epidermis. Mean \pm SD.

Surfaces of cow skins were observed by scanning electron microscopy (Figure 4). Comparing micrographs of the proteolytically treated and untreated skins confirms the dehairing action of the proteolytic samples, since hair and epidermis were completely removed from treated skins. Additionally, the clean hair pores would indicate removal of the hair from root without damaging hair (in fact it was observed intact hair into the incubating baths). The surface of depilated skins is the grain surface (upper dermis) and its structure is related with properties of final leather ${ }^{11}$. The dehaired skins display clean grain structures and although there are differences between their surfaces, no damage is observed.
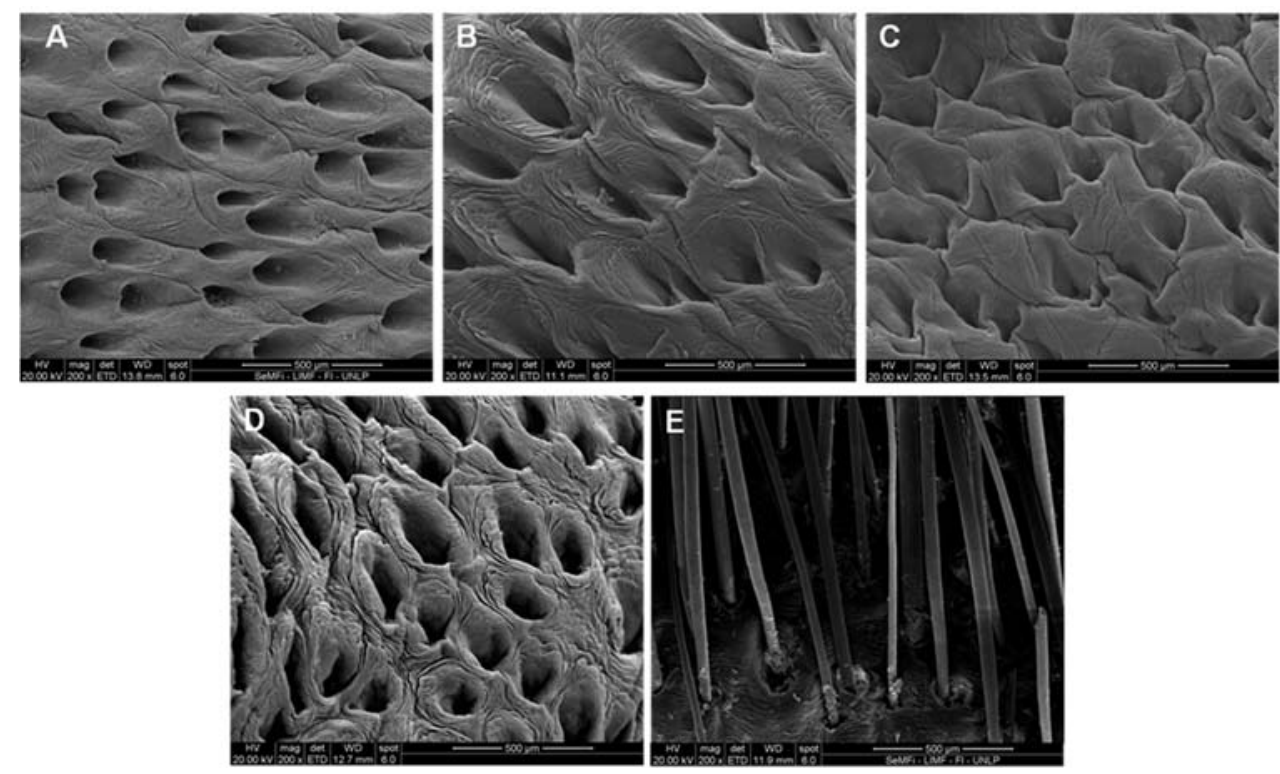

FIGURE 4. Scanning electron micrographs $(200 \mathrm{X})$ of grain surface of cow skins after treatment with: (A) $1 \mathrm{CU} / \mathrm{ml}$ of $\mathrm{Bb}$; (B) $1.5 \mathrm{CU} / \mathrm{ml}$ of $\mathrm{Bh}$; (C) $0.5 \mathrm{CU} / \mathrm{ml}$ of Pm; (D) $0.2 \mathrm{CU} / \mathrm{ml}$ of New1875; (E) reaction buffer (Control) 


\section{ISEBE Advances 2016}

Analysis by scanning electron microscopy of cross section of cow skins (Figure 5) showed no difference respect to disposal of the collagen fiber bundles between dehaired and control skins. Observations at higher magnifications did not show damage of collagen, while skins treated with $\mathrm{Bb}$ and $\mathrm{Pm}$ showed better opening of fiber bundles (data not shown).
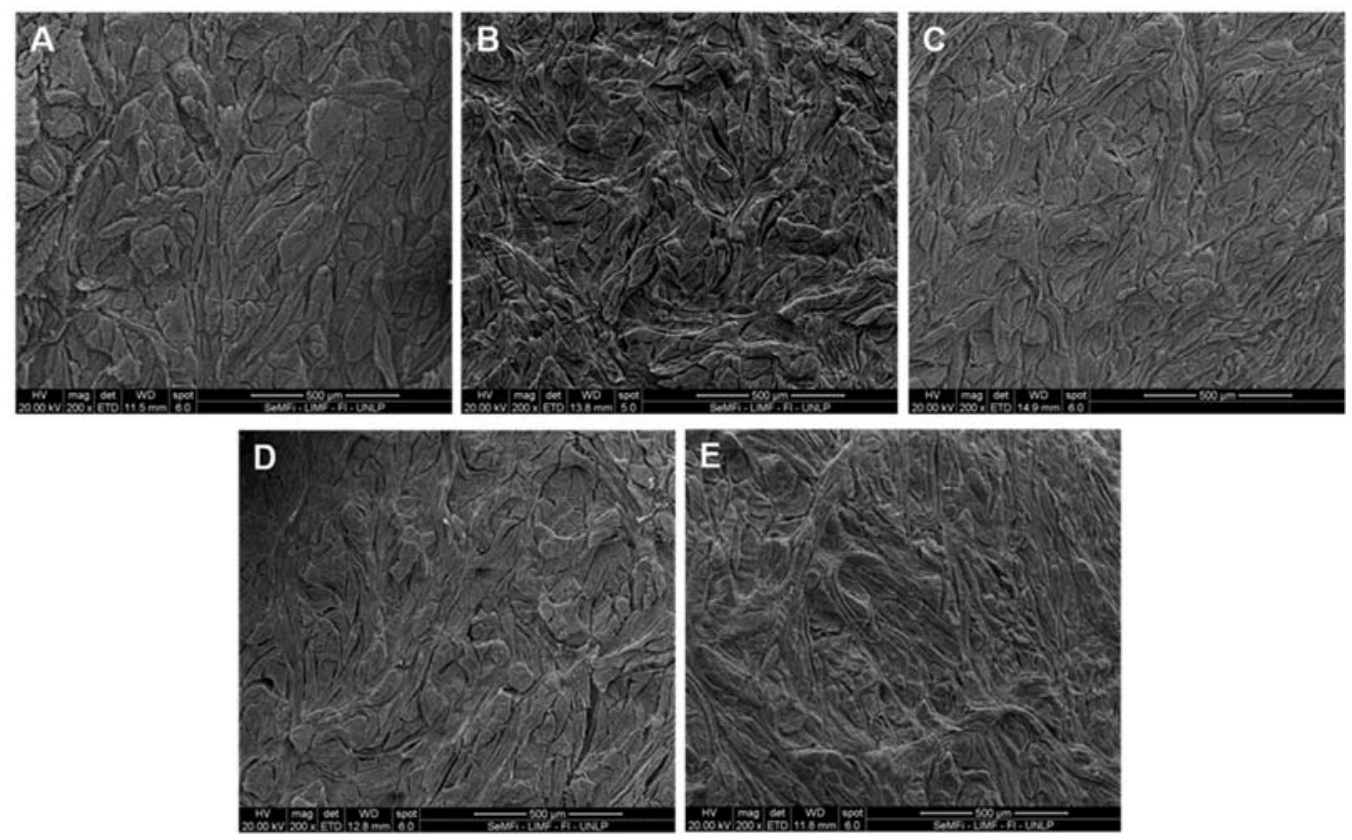

FIGURE 5. Scanning electron micrographs $(200 \mathrm{X})$ of cross section of cow skins after treatment with: (A) $1 \mathrm{CU} / \mathrm{ml}$ of $\mathrm{Bb}$; (B) $1.5 \mathrm{CU} / \mathrm{ml}$ of $\mathrm{Bh}$; (C) $0.5 \mathrm{CU} / \mathrm{ml}$ of Pm; (D) $0.2 \mathrm{CU} / \mathrm{ml}$ of New1875; (E) reaction buffer (Control)

\section{CONCLUSION}

Proteolytic extracts from fruits of Bromelia balansae (Bb), B. hieronymi (Bh), and Pseudananas macrodontes $(\mathrm{Pm})$ showed activities against representative substrates of skin, as keratin, collagen, elastin and epidermis. In view of these activities it could be expected different applications in leather industry. So, Bh could be proposed as a suitable soaking and bating enzyme due to its elastinolytic activity; all extracts could act like dehairing enzymes due to their activities against epidermis, while due to activities against the main skin proteins they could be used for treatment of waste from tanneries.

On the other hand, $\mathrm{Bb}, \mathrm{Bh}$, and Pm could depilate cow skin after incubating $24 \mathrm{~h}$ at $25^{\circ} \mathrm{C}$ and $\mathrm{pH} 8$. Furthermore, desirable characteristics of dehairing were observed since that hair pores did not show residual hair, grain surface of depilated skins were clean and intact, and collagen fiber bundles of dermis were not damaged. These findings, coupled with low keratinolytic activity showed, provide evidence that $\mathrm{Bb}, \mathrm{Bh}$, and $\mathrm{Pm}$ would be secure and eco-friendly dehairing agents suitable to leather process. Besides, due to observed differences in grain surface and opening of collagen fibers achieved by the different extracts, it is expected that $\mathrm{Bb}, \mathrm{Bh}$, and $\mathrm{Pm}$ will produce different types of leather. However, more studies are necessary to adapt these proteolytic extracts to 
entire leather processing as well as evaluate pollution parameters of process and physical mechanical properties of the final leather.

\section{ACKNOWLEDGMENTS}

Errasti, ME is CONICET fellow. Lopez, MIL is member of the CONICET Researcher Career. The present work was supported by grant from CONICET (PIP 00297). Authors want to thank to Germán Mazzill from technical staff of the CITEC (CIC-INTI), who performed the soaking process.

\section{REFERENCES}

1. Madhavi J., Srilakshmi J., Rao M.R., Rao, K.R.S.S. Efficient leather dehairing by bacterial thermostable protease. Int. J. Biosci. Biotechnol. 3 (2011) 11-26.

2. Saran S., Mahajan R.V., Kaushik R., Isar J., Saxena R.K. Enzyme mediated beam house operations of leather industry: a needed step towards greener technology. J. Clean. Prod. 54 (2013) 315-322.

3. Dixit S., Yadav A., Dwivedi P.D., Das M. Toxic hazards of leather industry and technologies to combat threat: a review. J. Clean. Prod. 87 (2015) 39-49.

4. Kanagaraj J., Velappan K.C., Chandra Babu N.K., Sadulla S. Solid wastes generation in the leather industry and its utilization for cleaner environment-A review. J. Sci. Ind. Res. 65 (2006) 541-548.

5. Dettmer A., Cavalli É., Ayub M.A., Gutterres M. Optimization of the unhairing leather processing with enzymes and the evaluation of inter-fibrillary proteins removal: an environment-friendly alternative. Bioprocess Biosyst. Eng. 35 (2012) 1317-1324.

6. Thanikaivelan P., Rao J.R., Nair B.U., Ramasami T. Progress and recent trends in biotechnological methods for leather processing. Trends Biotechnol. 22 (2004) 181-188.

7. Ramasami T., Rao J.R., Chandrababu N.K., Parthasarathi K., Rao P.G., Saravanan P., Gayathri R., Sreeram K.J. Beamhouse and tanning operations: process chemistry revisited. J. Soc. Leath. Tech. Ch. 83 (1999) 39-45.

8. Saravanan P., Renitha T.S., Gowthaman M.K., Kamini N.R. Understanding the chemical free enzyme based cleaner unhairing process in leather manufacturing. J. Clean. Prod. 79 (2014) 258264.

9. Sivasubramanian S., Manohar B.M., Rajaram A., Puvanakrishnan R. Ecofriendly lime and sulfide free enzymatic dehairing of skins and hides using a bacterial alkaline protease. Chemosphere 70 (2008) 1015-1024.

10.Arunachalam C., Saritha K. Protease enzyme: an eco-friendly alternative for leather industry. Indian J. Sci. Technol. 2 (2009) 29-32.

11.George N., Chauhan P.S., Kumar V., Puri N., Gupta N. Approach to ecofriendly leather: characterization and application of an alkaline protease for chemical free dehairing of skins and hides at pilot scale. J. Clean. Prod. 79 (2014) 249-257.

12.Choudhary R.B., Jana A.K., Jha M.K. Enzyme technology applications in leather processing. Indian J. Chem. Technol. 11 (2004) 659-671.

13.Foroughi F., Keshavarz T., Evans C.S. Specificities of proteases for use in leather manufacture. J. Chem. Technol. Biotechnol. 81 (2006) 257-261.

14.Aftab M.N., Hameed A., Haq I.-u., Chen R.-s. Biodegradation of Leather Waste by Enzymatic Treatment. Chin. J. Proc. Engin. 6 (2006) 462-465. 


\section{ISEBE Advances 2016}

15. Valeika V., Beleška K., Valeikienè V., Kolodzeiskis V. An approach to cleaner production: from hair burning to hair saving using a lime-free unhairing system. J. Clean. Prod. 17 (2009) 214-221.

16.Dettmer A., Ayub M.A., Gutterres M. Hide unhairing and characterization of commercial enzymes used in leather manufacture. Braz. J. Chem. Eng. 28 (2011) 373-380.

17.Pardo M.F., López L.M., Canals F., Avilés F.X., Natalucci C.L., Caffini N.O. Purification of balansain I, an endopeptidase from unripe fruits of Bromelia balansae Mez (Bromeliaceae). J. Agric. Food Chem. 48 (2000) 3795-3800.

18.Bruno M.A., Pardo M.F., Caffini N.O., López L.M.I. Hieronymain I. a new cysteine peptidase isolated from unripe fruits of Bromelia hieronymi Mez (Bromeliaceae). J. Protein Chem. 22 (2003) 127-134.

19.Bruno M.A., Trejo S.A., Avilés X.F., Caffini N.O., López L.M.I. Isolation and characterization of hieronymain II, another peptidase isolated from fruits of Bromelia hieronymi Mez. Protein J. 25 (2006) 224-231.

20.Bruno M.A., Trejo S., Caffini N.O., López LMI. Purification and characterization of hieronymain III. Comparison with other proteases previously isolated from Bromelia hieronymi Mez. Protein J. 27 (2008) 426-433.

21.López L.M., Sequeiros C., Natalucci C.L., Caffini N.O., Brullo A., Maras B., Barra D. Purification and characterization of macrodontain I, a cysteine peptidase from unripe fruits of Pseudananas macrodontes (Morr.) Harms (Bromeliaceae) Protein Expres. Purif.18 (2000) 133-140.

22.López L.M., Sequeiros C., Trejo S.A., Pardo M.F., Caffini N.O., Natalucci C.L. Comparison of two cysteine endopeptidases from Pseudananas macrodontes (Morr.) Harms (Bromeliaceae). Biol. Chem. 382 (2001) 875-878.

23. Brullo A. (2003), Aislamiento, purificación y caracterización de las endopeptidasas cisteínicas presentes en frutos de Pseudananas macrodontes (Morr.) Harms (Bromeliaceae). Ph. D. Thesis. National University of La Plata, Argentina. Available at http://sedici.unlp. edu.ar/bitstream/handle/10915/2246/Documento_completo__.pdf?sequence=23.

24.Bradford MM. A rapid and sensitive method for the quantitation of microgram quantities of protein utilizing the principle of protein-dye binding. Anal Biochem. 72 (1976) 248-254.

25.Cantera C.S., Goya L., Galarza B., Garro M.L., Lopez L.M.I. Hair saving unhairing process. Part 5 Characterisation of enzymatic preparations applied in soaking and unhairing processes. J. Soc. Leath. Tech. Chem. 87 (2003) 69-77.

26. Thompson V.F., Saldaña S., Cong J., Goll D.E. A BODIPY fluorescent microplate assay for measuring activity of calpains and other proteases. Anal. Biochem. 279 (2000) 170-178.

27.Cantera C.S., Angelinetti A.R., Altobelli G., Gaita G. Hair saving enzyme assisted unhairing: influence of enzymatic products upon final leather quality. J. Soc. Leath. Tech. Chem. 80 (1996) 8386.

28. Sivasubramanian S., Manohar B.M., Puvanakrishnan R. Mechanism of enzymatic dehairing of skins using a bacterial alkaline protease. Chemosphere 70 (2008) 1025-1034

29. Jaouadi N.Z., Jaouadi B., Hlim H B., Reki H., Belhou M., Hmidi M., Bejar S. Probing the crucial role of Leu31 and Thr33 of the Bacillus pumilus CBS alkaline protease in substrate recognition and enzymatic depilation of animal hide. PloS one, 9(9) (2014) e108367. 